\title{
Reading the Tea Leaves at Tea and More: Resolving Complex Supply Chain Issues
}

\author{
Barry Doyle* \\ Department of Finance \\ School of Business and Professional Studies \\ University of San Francisco \\ Email: doyleb@usfca.edu \\ Arthur H. Bell \\ Executive Director of MBA Programs \\ School of Business and Professional Studies \\ University of San Francisco \\ Email: bell@usfca.edu
}

\begin{abstract}
Tea and More is facing growing pains from its rapid expansion over the last decade and more. The case provides a summary of the challenges faced by the company in the areas of supply chain management, marketing plans, the creation of economic value, and the development of a long term strategy for profitable growth.
\end{abstract}

Keywords: supply chain management, small business

\section{The First Meeting}

Jack Reynolds hadn't panicked often since he and two business partners bought Tea and More (TAM) from its founders almost 16 years ago. As a purveyor of fine teas and assorted food specialties to upscale restaurants and gourmet shops, TAM had achieved a steady growth in market share and profitability since those early days when gross revenues were less than $\$ 1$ million and Jack knew most of his customers on a first-name basis. Jack had bought out his partners along the way, making decisions easier. He had grown used to calling the shots on even the most insignificant aspects of operations and sales.

But by early 2009, revenues had grown to almost $\$ 25$ million. Jack was putting in killer days and had earned a reputation within the company as a temperamental "time bomb" isolated in his corner office, where he regularly dispatched scorching emails and voicemails about his latest discontents. There was no denying that the company ached with growing pains. Jack snapped another pencil in half. Why did he always have to come up with the next good idea? TAM employees from top to bottom were privately feeling the weight of Jack's heavy

* Corresponding Author

This case was prepared solely to provide material for classroom discussion. The authors do not intend to illustrate either effective or ineffective handling of a managerial situation. The authors have disguised some names and other identifying information to protect confidentiality. The views presented here are those of the case authors and do not necessarily reflect the views of Operations and Supply Chain Management: An International Journal. Copyright (C) 2009 by Operations and Supply Chain Management: An International Journal and the authors. If you are an instructor and wish to adopt the case for your class, please contact the corresponding author or the special issue editor to obtain the teaching notes. 
hand on the tiller. Turnover was beginning to be a major problem, with valuable management time seemingly being wasted on trying to train yet another new hire.

Jack dashed off an email to his senior staff announcing a summit conference of sorts - a weekend retreat where they (or he) would get to the bottom of the problems facing the company: competitors fighting hard for more of TAM's market share; maddening delays and mixups in production; constant grousing from salespeople about too much travel for too little reward; and Jack's other laundry list of how his vendors, customers, employees, and office janitor were letting him down. Every aspect of the business, he told his people, was "going under the microscope" to "make this company run like it used to."

\section{History of Tea and More}

The company was founded in Los Angeles as Global Tea by three sisters in 1985 . They shared a love of fine teas and, prior to starting business, spent much of their vacation time tracking down unusual teas, specialty blends, and reliable producers around the world. They built up a tidy and satisfied retail customer base comprised primarily of restaurants and bakeries in California and eventually throughout other Western states. But the circle was broken in 1992 when one sister died of cancer. Their CPA at the time, Jack Reynolds, leaped at the opportunity to buy the business and talked two of his buddies into putting up most of the capital as not-so-silent partners. Jack had an eye for marketing and design. Within a matter of months he had transformed the look of his products with imaginative graphics, whimsical quotations, and brief, exotic product notes. Tea and More was born, headquartered in Los Angeles.

After two extraordinarily successful years converting TAM to a wholesale operation, Jack was able to buy out his partners and take over sole ownership of TAM as a privately held company. From time to time, as expansion dictated, Jack brought aboard a few investors, but never gave them decisionmaking roles. His senior staff consisted at first of a VP of Sales and Marketing and a VP of Operations. That small team grew over time to include an Executive VP ("someone who can communicate with
Jack") and six director-level positions for various business functions. No matter the size of this senior staff from year to year, Jack maintained absolute control over business decisions large and small. "Better check with Jack" became the mantra among increasingly cynical company executives.

\section{A Complicated Supply Chain}

When Jack acquired the company, his primary vendors in China and India were used to sending relatively small shipments on an "as available" basis. The founding sisters had focused on the art of selling to their retail market, not on the reliability, scale, or efficiency of their supply chain. At times, in fact, they enjoyed running out of their most popular teas so that their sales ingenuity could be challenged in selling more back-of-the-shelf varieties. Jack had a quite different vision and strategy. He almost immediately expanded his sources to include Japan, Sri Lanka, and Taiwan, while retaining his connections in China and India. But shipment size and reliability continued to plague the company throughout the mid-1990s.

Somewhat reluctantly, Jack weaned himself from direct import of his selected teas and struck an advantageous contract with a middle-man, Earl Morgan Limited (EML), based outside London. EML had for more than a century served as a worldwide processor of mainstream and exotic tea blends, all according to the specifications of their resale clients. Jack's company, for all its branding success in U.S. restaurants and gourmet shops, remained a "small potatoes" account for EML compared to the large grocery chains in the UK and Europe. Jack's orders for blended teas from EML were typically produced in batches twice a year. In more than one heated meeting, EML executives patiently explained to Jack that he could not afford their equipment setup and calibration expenses for more than two production runs each year. Especially since the shelflife of properly sealed tea was not at issue, Jack had every reason to purchase in bulk on a biannual basis rather than paying a stiff surcharge for more frequent production runs. EML shipped to TAM in container-sized lots, with each container holding about 10,000 kilos of tea.

Purchase orders for types and amounts of tea come from TAM's single production facility, located 
outside Cleveland, Ohio. The initial decision to have production in the center of the country rather than Los Angeles was motivated primarily by lower operating costs - both wages and facilities were cheaper in the Midwest. Further, the Production Chief, a tea guru now well advanced in years, simply refused to move to Los Angeles - and, for once, Jack backed down to preserve the value that this key individual brings to TAM's many tea products. The Production Chief oversees the art of ordering the right blends in the right quantities for a somewhat unpredictable market (influenced by changing public tea preferences, the rise of competing beverages, and the overall economy). If a particular tea source is unavailable, a substitute ingredient must be identified by the Production Chief prior to placing one of TAM's production runs with EML in London. But because any product changes have to be explained to TAM's salespeople and reflected in its advertising, the Production Chief must clear any alterations to tea formulas with the VP of Sales and Marketing, based at headquarters in Los Angeles. Such clearance isn't pro forma. Often samples have to be shipped to Los Angeles; dozens of communications flow back and forth, sometimes over a period of weeks. Other factors explaining a continued production base in Cleveland include favorable tax conditions; cheaper, more reliable labor than in the Los Angeles area; and affordable housing for the dozens of employees involved in the production process.

The whole matter of order definition and compilation is made even more challenging by the three-month lead time required by EML in London for any production run. EML says it needs two months to acquire the selected tea from its Asian or Indian source and one month for shipping (via freighter and truck) to TAM's production facility in Cleveland. TAM maintains standing orders with EML for its most popular high-volume teas and the arrival of these teas, sealed in large bags, can be predicted twice a year almost to the day. Less popular teas, however, arrive with less regularity, since they depend on being "worked in" to openings in EML's long queue of production runs.

Once unloaded in Cleveland, the tea is packaged into retail containers. At full capacity, the processing plant can package about $\$ 100,000$ of tea per day (about 20,000 lbs). The packages are then 'shelved in the production facility until being shipped to the retailer. The Cleveland facility usually warehouses about two months of sales as inventory. But that estimation is typically just a guess. Order volume varies by season and even within seasons, if a cold spell brings out more teapots or a hot summer more iced tea. As a rule, and in spite of TAM's efforts to educate them, retail customers tend to under-order when they place their major tea purchases two or three times a year. When their tea runs out, or a particularly popular blend goes empty on the shelf, these customers frantically contact the Los Angeles sales staff, who in turn check the inventory in Cleveland-and the shipping time to meet the customers' emergencies. Sometimes the right teas are available in Cleveland and can be transported quickly, if expensively, to the retailer (who absorbs the extra shipping charges, usually air freight). Just as often, however, Cleveland has to report back that the requested type or amount of tea isn't in inventory and won't be available for a matter of months. Customers blame TAM and TAM blames the customers' ordering practices.

\section{Customer Servicing}

TAM employs three full-time sales representatives, each with responsibility for major accounts within a region of several states. Smaller accounts are serviced by "contract sales staff" - i.e., salespeople who represent a number of product lines to relatively minor clients such as individual restaurants and Mom and Pop grocery stores. Relations with these contract sales personnel have become increasingly rocky over the past year. With the increase in gas costs, sales men and women complain to TAM that they can hardly afford to make even irregular calls on smaller, distant clients. For their part, these clients complain to TAM that they haven't seen a sales rep for months and are forced to either abandon the TAM line or order it on-line, thus incurring additional shipping expenses. These on-line sales further anger the contract sales people, since they receive no commission when an order goes through the on-line purchasing center. For several months these outside sales personnel have lobbied TAM for some kind of commission whenever an order comes from their territory, even if it comes on-line. TAM has resisted this arrangement, fearing that it will further encourage sales people not to make in-person calls on their clients. 
In total, these smaller sales account for about 15 percent of TAM's business. Jack Reynolds and other company leaders have long suspected that better customer service could bump up this percentage substantially. For example, when a small retailer's shelf is empty of TAM teas, all it takes is a competitor on the spot with a ready deal to fill that shelf. In such cases, TAM may have lost a customer forever. TAM leaders have tried a carrot approach in offering a 12 percent commission instead of the usual 10 percent commission to outside sales people. They have also tried the stick approach, by threatening to change sales vendors entirely unless customers begin receiving better, more regular service. But outside sales people seem to be impervious to either attempt at motivation. As one sales person put it, "An extra 2 percent commission doesn't cover my extra gas and time. And if they want to fire us, let them. We have plenty of brands to represent besides TAM."

\section{Payment Terms}

TAM's customers are technically on a "net 30 " basis, with the thirty days until payment due beginning at the time that an order is shipped from inventory stored in Cleveland. TAM still uses regular mail for sending invoices, although some customers have been willing to receive invoices by fax. In spite of the "net 30 " requirement, the average collection period across all clients is 54 days. To date, TAM has not charged interest on balances less than 90 days in arrears, out of a concern for keeping good customer relationships. Customers with a poor or missing credit history are required to pay by credit card, on which TAM pays a 4 percent surcharge, or in cash, which is handled primarily by outside sales people before being turned in (twice a month) to the Los Angeles office. The handling of such cash has been sloppy at best over the years. Some sales people subtract what they calculate to be their commission before turning in the remaining cash, a practice that TAM leaders have tried repeatedly to stop.

\section{Product Variety}

Motivated in large part by requests from large restaurant chains, TAM has nearly doubled the types of teas it sells over the past two years. New varieties pique the interest of the sales staff for a brief period, giving them a new "story" to tell their customers. But in general the retail and wholesale market has preferred to stick to the five or six traditional tea varieties produced by TAM. Financially, the effort to expand company sales by coming up with new tea tastes, labels, and packaging has proven to be a "bust" for the company-an expensive experiment that failed. Yet TAM leaders have noticed that competitors seem to have good luck with catchy new tea varieties, particularly those targeted for holiday season marketing. "What are we doing wrong?" Jack Reynolds has asked aloud many times. "We have a superior product, but our competitors are beating our socks off by eye-catching displays and a lot of magazine advertising." Yet he has been reluctant to approve marketing budgets to match those of competitors when it comes to untried new TAM products.

\section{Product Pricing}

In TAM's early years, retail customers-patrons of restaurants and shoppers in grocery stores and beverage shops-seemed oblivious to price. In several controlled marketing studies, TAM teas seemed to achieve the same level of demand within a 20 percent price swing up or down-customers simply wanted quality tea and were willing to pay for it. In the last 18 months, however, all aspects of TAM's operation from materials cost to labor to shipping have become significantly more expensive. In response, the company has "pressed the upper envelope" of pricing to 25-30 percent above previous levels. This raise in price has unfortunately created room for lower quality tea producers to gain market share by selling to TAM's former customers at a much reduced price, often as much as half of what TAM charges per product unit. TAM has emphasized the high quality of its teas in expensive advertising campaigns and direct mail "specials" targeted at new and old customers. But these expenses have further eroded profit margin. "We're giving our tea away!" Jack Reynolds has complained. "Let's get back to basics and sell our traditional line of teas to our loyal customer base. Forget the low-price market!" Jack's company associates have been reticent to remind him that his so-called "loyal customer base" has been increasingly lured away by competitors with so-so teas but very attractive pricing. 


\section{The TAM Summit Conference}

At the weekend "summit conference" called by Jack to deal with these company dilemmas, senior staff first had to endure hours of Jack's ranting about what each of them were doing wrong, how he was been cheated by outside sales people, how previous customers had no sense of loyalty to TAM, and seemingly endless other issues. When Jack tired, he passed out a single sheet containing six questions to be addressed by senior staff. With a flourish, Jack locked the door to the meeting room shortly after lunch. "And until we have answers," he proclaimed, "no one is leaving. I don't care if it takes all night."

\section{Discussion Questions}

1. What can we do about lost sales due to poor customer service by outside "contract" sales staff?

2. How can we restore the attractiveness and power of the TAM brand for major customers so they aren't lured away by low-cost, low-quality competitors?

3. How can we minimize "stock outages" and other inventory problems caused by unpredictable customer ordering patterns and the continuing difficulty of getting faster production and delivery from EML in London?

4. How can we reduce collection time from 54 days to less than 40 days without alienating the very customer base TAM was trying to attract and retain?

5. What decisions should we make regarding experimentation with new tea varieties, such as the "Christmas Mint" tea that fell flat last season? Can we afford to continue such experiments? Can TAM afford stick only to its basic teas and not compete in the "new and improved" tea market so heavily advertised by competitors?

6. What haven't we thought of? Where else can financial advantages and process efficiencies be achieved?

Barry W. Doyle is Professor of Finance at the University of San Francisco. He is chair of the Finance department and director of curriculum development for all MBA programs at the University. He has coordinated several overseas MBA programs in China using distance learning as well as been an architect of the current Executive MBA program at USF. His research has been published in European Journal of Operational Research and Journal of Financial Planning.

Arthur H. Bell is Executive Director of MBA Programs and Professor of Management Communication at the School of Business and Management, University of San Francisco. He holds his PhD from Harvard University and is the author of 51 books on management, communication, language, and literature topics. His most recent books include Management Communication 3e (Wiley, 2009) and Winning with Trust in Business, with Richard Cohn (Pelican, 2009). 
APPENDIX 1

\section{SUMMARY FINANCIAL STATEMENTS ('000)}

Revenues

CGS

SG\&A

Deprec

EBIT

Interest

Tax

Net Income

Cash

$\mathrm{A} / \mathrm{R}$

Inventory

Current Assets

Net Fixed Assets

Total Assets

Accounts Payable

Other Current Liab.

Notes Payable

Total Liabilities

Owners Equity

Total

\begin{tabular}{rrr}
2006 & 2007 & 2008 \\
\hline 18,065 & 20,210 & 22,500 \\
9,600 & 10,850 & 12,300 \\
4,560 & 5,300 & 6,100 \\
1,050 & 1,050 & 1,050 \\
\hline 2,955 & 3,010 & 3,050 \\
75 & 75 & 75 \\
1,252 & 1,294 & 1,310 \\
\hline 1,628 & 1,641 & 1,665
\end{tabular}

$\begin{array}{r}100 \\ 2,600 \\ 1,850 \\ \hline 4,550\end{array}$

$\begin{array}{r}100 \\ 2,950 \\ 2,050 \\ \hline 5,100\end{array}$

100

3,350

2,400

5,850

$\frac{2,500}{7,050}$

$\frac{2,550}{7,650}$

$\frac{2,600}{8,450}$

\section{Selected Ratios*}

1,200
200

900

2,300

$\frac{4,750}{7,050}$
1,320

230

900

2,450

$\frac{5,200}{7,650}$

1,490

250

900

2,640

$\frac{5,810}{8,450}$

Oper. Profit Margin (\%)

Net Profit Margin (\%)

Avg. Coll. Period (days)

Inventory T/O (CGS/Inv)

$\begin{array}{rr}16.4 & 14.9 \\ 9 & 8.1 \\ 52.5 & 53.3 \\ 5.2 & 5.3\end{array}$

13.6

7.4

54.3

5.1

Ind Avg*

* Industry Averages are approximate; data from comparable firms is difficult to obtain with any reliability. 